\title{
Knowledge of the Lord in the Hebrew Bible
}

\author{
SIMEON CHAVEL, UNIVERSITY OF CHICAGO DIVINITY SCHOOL
}

\section{The Hebrew Bible}

By contemporary accounts, the traditional Jewish Bible is an anthology of Hebrew pieces of literature from ancient Israel, Judea, and Babylon. Its materials-compositions, collections, collated fragments, and more-span the ninth to second centuries BCE, from the period of Assyrian domination, through the Babylonian and Persian, and into the Hellenistic. Sociological and technological developments in the late sixth century BCE made large, durable parchment scrolls available to Judean text-professionals, and prompted their idea to use them to store the valued contents of the smaller, less durable papyrus ones that had long served and predominated, in particular papyri featuring the nation's god and heroes. Over several centuries, text-professionals gathered the papyrus remains of earlier periods and contemporary works too, collating and editing them. ${ }^{\mathrm{I}}$ The literary record from the fifth century BCE to the first century CE, in the Persian and Hellenistic periods, shows that this concentrated, controlled storage-ancient "big data"went beyond aiding preservation to facilitate a vibrant culture of mastering the contents, hermeneutic engagement, adaptation in new works, public reading events, literal and political applications, text-centered

(C) 2018 THE UNIVERSITY OF CHICAGO. ALL RIGHTS RESERVED. KNOW V2N1, SPRING 2018 
sanctity, and even divine access. Entire Judean communities defined themselves and distinguished themselves from others by their specific textual corpus and by the interpretations, beliefs, and practices they anchored in it. For those Judeans, knowledge of the texts was knowledge of the Lord and of the world he created and continues to control. ${ }^{2}$

In the ancient papyri gathered up-sophisticated narratives of the past, pious hymns chanting deeds of yore and plaintive petitions seeking more, prophecy about dawning times and distant, sage discourse on worldly success-the authors of old expressed their own precious, foundational knowledge of the divine. No abstract propositions or esoteric insight, such knowledge consists of a set of characteristics deeply integrated with knowledge of the world, its composition, and its mechanics, including its humanity. Of no fixed form, this integrated, embedded knowledge shifts with the literary medium that presents it: it is a function of genre.

To most contemporary scholars of the Hebrew Bible, genres reflect public institutions and settings-political, economic, social-each of which held distinct ideas about the deity and a signature way to express them, but biblical literature as it is now has been supplemented and revised at so many points and in so many ways as to disfigure the texts and occlude the window they provide onto the ancient institutions and settings. To encounter the ancient views of divine knowledge, one must identify the original form and extent of the text and, behind that, the expression of that original setting in which its articulation would have been fully meaningful. In this view, literature carries the voice of the collective and its speech is that of types-the personas that represent those collectives. On the one hand, in this view, literature that looks realistic enough affords one reasonably confident access to the real past. On the other hand, literature is an impediment to speech to be overcome, an obstacle to its proper audition and comprehension. Authentic knowledge is expressed orally, directly, and 
a flattened, distorted form of it. Some scholars valorize the supplements and revisions both as creative and as reflective of subsequent times and interests that can be recovered, but they do not alter the basic idea of literature as removed from the real, as a misted window upon which would-be observers have breathed and smeared new patterns through which deludedly to try and glimpse it. To all such scholars, one who can follow the collective voice can trace collective change, count causes, account for results, and recount the past; one can narrativize an entire society, write its history, and have encompassing knowledge of it, including its divine element. Not only does the Hebrew Bible tell a single encompassing story, but the story told rebounds to the Hebrew Bible itself, accounting for its current form, which reflects the unfurling knowledge of the deity. ${ }^{3}$

In an alternate view, literature does not make a prior event available or transmit preexisting content, but creates an immediate eventthe reading experience itself. In this event the writing is either read and heard internally (as in modern times) or read aloud and heard by an audience (as in ancient). Literature triggers this event by simulating a speech event, speech that posits a past, a present, or a future and constructs it as it goes. Literature prompts its audience to participate in a virtual reality. Genres, in this view, are the textual simulation of different live speaking situations: a storyteller, a cultural critic and prognosticator, a teacher, a philosopher, a lover, the bereft. Literature, in this view, has agency. That agency is set in motion by authors, and authors can exploit the possibilities afforded by textual simulation to widely varying effect. They choose their points of verisimilitude and of unreality, where to distract from the artifice and where to accentuate it, where to indulge the audience's desire for virtual reality and its ready suspension of disbelief and where to put the audience to the test. ${ }^{4}$

In this view, works gathered in the literary treasury that is the Hebrew Bible came to exist through individual authors, who rather than record or transmit institutional or collective knowledge of the deity, 
drew upon their cultural lore and personal experience in a novel way to construct knowledge and argue it. The speakers of the texts they produced, rather than immediately represent a collective, have individuality. Each simulated speaker mimics a known speaking situation and stretches it this way and that, according to the author's design. No authors identified themselves; some cast the simulated speaker as a legendary figure, like Moses, David, or Isaiah. And each of the simulated speakers, given its discrete outline and setting, proposes distinct knowledge of the deity.

But the biblical treasury primarily comprises treasury-like workscurated collations and simple collections produced by editors-and most of the authored works hide in these, woven all together or juxtaposed alongside each other. Having worked not to produce a consistent level of simulation and argument but to gather by rolling sets of criteria, association-clusters around specific persons or types, editors produced composite works that obscured voicing, suggested new, complex super-genres-new forms of divine knowledge-and, so difficult to synthesize, facilitated selective retelling in yet new works (in ancient times) or historicizing the embedded works and the real-life phenomena seemingly made available by them (in modern times). ${ }^{5}$

This emphasis on authors and arguments, on textualized speakers and genres, on editors and complexes, and on the historical role of technology and society in literary culture, foils contemporary attempts to narrativize ancient society and divine knowledge on the basis of literary remains. It recasts the Hebrew Bible from a story perceptible to contemporary readers to an ancient treasury for ancient readers that might be used so again, entirely subject to new realities-new mores, new aims, and new modes. The new review below of several works in the biblical treasury from this point of view aims to illustrate how biblical authors, who mostly refer to their deity by the proper name yhwh "Yahweh" or the general descriptions elohim 
different way; how they challenge existing rubrics and innovate; and how they exploit the literary medium to do so. It is a review of genremakers and genre-breakers.

\section{Kings and Prophets on History}

The most visible set today of ancient claims to divine knowledge is that of royal figures. Across the entire region of Southwest Asia, from Judea and Moab through the kingdoms of the Hittites and Arameans, to Assyria and Babylonia, ancient rulers employed stone but also other media, enduring and perishable alike, to recount their massive deeds-of conquest, security, procurement, construction, commerce, wealth, justice, and education: order and civilization-accomplished with divine charge, power, and wisdom. ${ }^{6}$ Literary works and fragments throughout the Hebrew Bible show Judean rulers and likeminded authors to have participated fully in this culture of divine knowledge based in the material and sensory. ${ }^{7}$ So certain of this historical knowledge were they, in which control over the landscape and change to it wrought by human hand bespeak divine cause, that they took the royal realm as the ground for construing the divine and then, in return, considered the royal realm a miniature of the divine, a diminished imitation. ${ }^{8}$ And so certain was this sensory knowledge that even political and social critics, authors simulating prophetic figures, ground prophetic knowledge in physical and visual proximity.

At one point in the book of Isaiah (6:I-I3) - which gathers materials allegedly spoken by the prophet Isaiah in eighth-seventh centuries $\mathrm{BCE}$ Judea, told of him, or otherwise associated with him-Isaiah speaks in the first-person voice about an event from long, long ago, when he found himself standing in Yahweh's palatial, hypersensory space peopled by fiery creatures, filling with smoke, thundering with their cries of praise for Yahweh, whose robes overrun the space. Yahweh had a mission and needed an agent, but for Isaiah to volun- 
teer and speak for Yahweh, his lips first had to be seared with a coal from Yahweh's altar, too hot even for a seraph to hold in its hands. The mission, though, was to disorient the people, dull their senses completely, and lead them to their doom. The author of this text may mean to explain years of a failed policy, ${ }^{9}$ but does so by a contrast in sensory mettle: the prophet Isaiah can perceive the divine and therefore represent him, while a people so dull can merit only further dulling. Many other texts in the Hebrew Bible similarly deploy the motifs of acute senses, physical proximity, and a confidant's access to divine presence in order to curate authenticity. All feature a

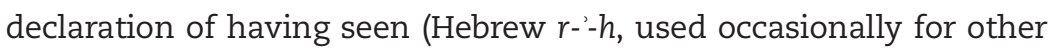
senses too). ${ }^{\text {. }}$

In a world of sensory knowledge by ruler and prophet alike, coalescing circumstances prompted one author to deny the logic, in a distinct work found at Isaiah 40-48. ${ }^{\text {I I }}$ Cyrus of Persia had recently captured Babylon (539 BCE) and explained it as the will of the Babylonian god Marduk, who appointed him to restore religious order. ${ }^{\mathrm{I} 2}$ Expatriate Judeans - those who arrived in Babylonia in the forced migration of elites in 597 BCE, those who arrived in the forced migration of the broader population in $586 \mathrm{BCE}$, and those born to the deportees in Babylonia-surely acknowledged the familiar and powerful claim: who but the successful king would know the source and purpose of his success? But the author of Isaiah 40-48 set out to convince the community of expatriates that Yahweh not Marduk stands behind Cyrus's success and that he does so to lead them to Judea, restore its towns, and rebuild Yahweh's own home there, the temple (44:24-45:7). His argument works by denying the logic of sensory, especially visual, knowledge. Those espousing the circular logic that discovers divine will-what they see generates backward what they know-also engage in the most absurd denial of sure knowledge: they employ every one of their senses and skills patiently and diligently to sculpt a statue 
but then deny the entire process and worship it as inhabited and animated by a god (44:6-20). The senses mislead and they are misused. The truth is in several inverses: Yahweh has no earthly home, no human corps, no king, but these make up no basis for judging his potency and relevance anyway. The deeds of old sung about for ages and never denied continue to herald deeds to come; embodied, sense-bound, and mortal creatures have not the perspective to determine the creator's will, plans, methods, and means, when he sets a plan in motion or brings it to a close. Creatures are but characters in the history he authors; their senses senseless, unable to identify an effect and link it to a cause, they are blind, deaf, mute, and ineffectual. The only point of access for the human creature, therefore, is one of human will, the will to hear and to obey (both within the semantic range of š-m-', like "listen").

True to the argument, the author of this text complicates the notion of hearing, chiefly in two ways. First, all the normal channels of direct communication are recast as highly mediated and dynamic. The prophet does not hear Yahweh stating clear instructions to a fixed council of subordinate divinities. Rather, he hears multiple voices (qol) coming at first from nowhere identifiable. They coalesce and crystallize into a single voice as they speak, and that speech cites Yahweh, who is sheer will (40:I-8). The prophet hears it and relays it, gives it human voice. At one richly ambiguous point (48:16), he declares that Yahweh sent him either together with his spirit-wind (ruah) or as his spirit-wind. Second, the prophet does not recount an aural event that has occurred in the past, recent or distant. He reports in real time on what he hears as he hears it. Several models suggest themselves for such a text: (I) a letter, in which the addressee treats the voicing as if it occurs with the reading and identifies the wording with the author, although the author wrote it in the past and is not directly present; (2) communication across a valley, in which the recipient can 
see the physical gestures of will and effort by the source, wind carries the voice across the valley, possibly echoing as several voices, and the recipient then hears it; and (3) a spirit medium, who gives real-time voice to the will and sentiment of the divine or otherworldly.

Textualizing and analyzing prophecy this way, the author can have Yahweh, through the voice and through the prophet, refer to the prophet, such that the prophet voices speech that is about him. True to the argument, when Yahweh does so, he describes his human herald as devoid of the normal human senses, because hearing Yahweh is not an act of body-bound perception but of will (42:19). The effect of this textual simulation of a real-time prophetic event makes the text's audience the direct recipients of prophecy, as if they made oracular inquiry and receive now divine response-each and every time the text is read. What do recent events mean? That expatriate Judeans in Babylon should ready themselves to move to Judea.

\section{Poetic Proverb and Prose Philosophy on the Quotidian}

The royal figure lent itself to an additional form of knowledge, the verbal arts. As the prose narrative winds its way through the book of Kings, the narrator describes the young king Solomon having earned divine wisdom, the power of discernment, through humility and prudence, then applying it (I Kings 3:3-28). Faced with two indistinguishable women, who live together in the same manless house, gave birth together, and after a crib-death now both claim motherhood over the single live infant, Solomon cuts the Gordian knot through a deepstructure play on the word for both cutting and deciding (g-z-r). His ruling, the decision to cut the live baby in two and award each woman one half, elicits compassion in the real mother, who withdraws her claim, and satisfaction in the mother of the dead infant, who declares 
up, portraying Solomon as, infused with divine wisdom, one who "spoke" (d-b-r) three thousand proverbs, "had" (h-y-h + l-) one thousand and five songs, and "discoursed" (d-b-r) on the entire plant and animal kingdoms (I Kings 5:9-I4). He mastered life through language.

Solomon the master speaker figures prominently in the book of Proverbs, a collection of about nine works that together make up a compendium of types of discourse about the way of life, its challenges, traps, and rewards, its poetry and its irony, and how to master it. ${ }^{13} \mathrm{He}$ appears at the head of the book, which in a preamble promises that its content-whether the entire book or the first work in it remains unclear-will not only help one live life successfully but also cultivate intellect and, ultimately, sharpen linguistic skill. The opening work contains a series of pieces framed as the direct-address speech of parents to their child; they advise by laying out extended scenarios or lining up pithy sayings, which carry the knowledge of experience and transmit it to the next generation. The next work, the largest in the book by far and likewise headed by an attribution to Solomon, presents unframed, rambling strings of one-liners, like a treasury of quotables that the quick-witted would know how to select, wield, and deploy. The other sections offer varieties of witty speech, from riddles to poems, in various sequences by varied speakers with varying, often exotic attributions. But they are all animated by the idea and simultaneously express it that speech can capture everyday life, its rhythm and its rhyme, by reducing it to representative images or illustrative scenarios of cause and effect in sayings of balance and measure-as poetry. This poetry, alternately presented as "wisdom" and personified as "(Lady) Wisdom," is identified with Yahweh himself; it is his gift to humanity, a medium of insight and control, a tree of life (3:I3-26; 8:I-36).

The author of the book of Ecclesiastes, or Qohelet, explodes the clarity and the causality, the symmetry and the poetry, of proverbial speech, 
and presents a broken chain of transmission, in which a teacher addressing his pupil (perceptible in I:I-2; 7:27; I2:8-I4) quotes the long, rambling, iconoclastic "last lecture" he had heard from his own teacher. The uncertainty of knowledge, in this work, the provisional nature of thought, begins with this quoted character, who is referred to at times by the proper noun "Qohelet," a particular person (I:I-2, I2:9-IO), and at others by the descriptor "the qohelet," a type of person, one defined by a particular activity, that of drawing crowds (7:27; I2:8). ${ }^{\mathrm{I}}$ Both the quoter and the quoted refer to him as a son of David and king over all Israel in Jerusalem (I:I, I2), which suggests Solomon, but three times the character also declares having far surpassed all those who preceded him in Jerusalem (I:I6; 2:7, 9), the rhetoric of which requires a long line, not just David. He says of himself, "I was king" (I:I 2$) ;{ }^{15}$ former US presidents might travel the world lecturing wisely, verbosely, and lucratively on life, but former kings are dead kings in the ancient world. At an early point in the speech (after chap. 2), the royal voice dissipates entirely into that of the sage; the quoter too comes to refer to the quoted as a "sage" not as king (I2:9-I2). The author shifts, re-presents, and reconstructs the figure-repersonifies it-as the text goes; he values evocativeness over realism. Quite literally, Qohelet the qohelet is a figure of speech: he speaks and he exists as others speak of him. ${ }^{16}$

The uncertainty of knowledge and the fragility of its transmission occur most potently at the work's end. The author does not give the pupil voice, but when the teacher concludes, the pupil's face must register shock and dismay, because the teacher promptly works to reverse all he has just quoted with a string of comments (I 2:9-I4): (a) Qohelet in his time did compose many pithy proverbs to educate the people, as befits the adroit scholar that he was; (b) a single coherent, thoughtful, and, yes, concerned mind does stand behind the grating bunches of barbs that seem unmanageably to cut against one another, for it is but the nature of such agglomerations to be unwieldy and 
tangled up; (c) too much collating and copying - the wearisome lot of the scholar or the scholar-in-training-can embitter a person; and (d) when all is said and done, best not to allow the intellectual exercises and acrobatics of scholarship to undermine one's subservience to God and observance of his commands, the true measure of a man. Not only has this teacher failed to transmit his teaching to his pupilthe wisdom of his own teacher-but he has evidently misjudged the readiness of his pupil, a categorical failure; the proverbial three-ply cord said reliably to hold fast (4:9-I2) threatens to snap.

And the uncertainty of knowledge is precisely what Qohelet describes. Qohelet talks about his past, where he began, realizations that shook him, a journey he undertook, and the understanding he achieved (I:I-3:I5). He says he is a former king over all Israel, who saw all manner of success. He built massively, gathered a teeming entourage and household, amassed farm animals manifold, planted luxuriantly, produced crops in abundance, brought in precious metals and exotic goods, commanded a diplomatic army, owned the finest talent in entertainment, and spared himself no self-indulgence. He far surpassed all who came before him, he says, in Jerusalem; he was the poster child for proverbial wisdom, for lessons learned with the listening ear and transmitted, for the road to riches, for mastery of the reason and the rhyme of life. He was the princely counterpart to the female personification of wisdom in the book of Proverbs, the one she beckons and guarantees health, wealth, and happiness. But he had a series of realizations that challenged traditional, proverbial wisdom. He came to see with his eyes that death does not distinguish between the successful and the sad sack. It renders assets useless and the effort to gain them fruitless. Nor can Qohelet guarantee his assets' fate, that they will not be squandered by his successor, that he himself will possess them until his death, or that God has not used him to favor another. A contemplative variant of the superhuman Gilga- 
mesh, Qohelet was haunted not by the certainty of death but by the uncertainty of everything else. So Qohelet resolved to examine the proverbial wisdom by which he had lived-cause and effect, comparison and application, restraint and reward, the reason and rhyme of lifeand ascertain its difference from folly, for if even a king could not guarantee such a thing, who could?

Three aspects of Qohelet's speech manifest his empiricist's denial of proverbial rhyme and reason: (I) his emphatic grasping through sight $\left(r-^{-}-h\right)$ rather than hearing/obeying $\left(\check{s}-m-{ }^{\prime}\right)$, a heightened sense of self marked by the first-person pronoun, and "talking with" his "heart"; (2) his citation and negation of proverbial utterances; and (3) his resolute use of prose over against the poetry of proverbial utterances. The coincidence between form and content is not serendipitous. The parallel structure of poetic lines expresses by implication, by inviting comparison, and it generates synthesis. Poetry works by its patterning of speech; the patterns generate knowledge and understanding in the interplay between repetition and variation, between expectation and surprise. This kind of thought process characterizes proverbial wisdom, which represents an entire set of related scenarios in the form of one paradigmatic case that embeds a principle that applies to them all. Proverbial wisdom draws on the patterns identified in life, reduces them to a formula, and controls outcomes. Qohelet rejects the existence of patterns and their implications of predictable, bankable causality. There are only accidents and outright repetitions, utterly useless repetitions that cause no change, that produce nothing. Often, when Qohelet does wax proverbial and poetical, he is being ironical.

Qohelet reviews many of the conventional pieces of wisdom he had examined on a host of matters in a variety of settings, citing them to discard them, even composing his own to parody them. Proverbial wisdom trades in life's patterns, formulas of action and result, guarantees of work and yield: who lives in its constraints will have no complaints. It expresses them in pithy sayings of balance and mea- 
sure, in puzzling series of poetic lines, and in whole poems of voiced instruction. And these offer quotidian, quirky, or cryptic situations that only the clever can enjoy, decode, and apply. Qohelet came to deny the proverbial predictability of life, the rule of causality, wisdom through formula. In his newer, prosaic view, life comprises utterly useless repetition and singular accidents. The wise thought the proverb ineffectual and self-pricking in the mouth of the fool, like the legs of the lame and the rose-stem in the hand of the drunk (Prov. 26:7, 9); Qohelet found the proverb itself useless and the wise self-pricking.

Qohelet begins his lecture (I:I-I I) by highlighting the useless repetition, illusory dynamism, and utter stasis of the world's elements in their spheres (the earth, the sun in the sky above it, the wind at its surface, and the water running through it and below) and of human cognitive organs and processes (speaking, seeing, and hearing). Then he turns to the accidental dimension, treating at length its relentless attack on human knowledge and control.

In one instructive instance Qohelet cites a proverbial piece of wisdom, "who does as told misfortune will not know," whose rhythm and rhyme serve its reason (cause and effect); then he offers the more knowing insight born of experience, "but timing and course of action does the astute mind discern" (8:5). Mindless obedience does not guarantee good fortune and results; the wise improvise. Qohelet's quip balances the proverb, creating a couplet of thought and counter-thought, one that turns on the root "to know, knowledge" $\left(y-d-{ }^{\prime}\right)$. The proverb applies the root to a passive experience-an experience to be avoided, knowledge never to have; the quip reapplies it to active participation in the event, shaping it and turning it to advantage. The quip also pits "course of action" (mišpaț) against "commandment" (mișwah), which typically it complements. Qohelet does not end the point here, but elaborates (8:6-7): every endeavor has its unique timing and course of action; on the whole fate and misfortune overwhelm a man, who knows not what will come next, and when it does 
come no one will tell him it is what is next, consequence, and not something wholly other, coincidence.

Similarly, earlier in the lecture (7:I-6a), Qohelet first quotes a proverbial series about values and practices. Reputation (which subsists) trumps rubbing oil (which dissolves); the day of death (one of triumph), that of birth (all needs and no deeds); the house of mourning, that of feasting, when death and reputation are on instructive display. So too, vexation trumps joy and chastisement tomfoolery for their edifying effect. Then (7:6b) Qohelet punctures the series with a counterproverb that the wise are themselves fully susceptible to whim and greed: "But this too is untenable, for ungainly gain makes fools of the wise and a gift dispenses with sense." ${ }^{18}$ Even those recognizing circumstances cannot control them.

Later on in his speech (9:I I), in classic proverbial fashion Qohelet offers a symmetrical list of paradigmatic cases to illustrate a counterproverbial point of his, that neither innate talents nor learned skills guarantee success-not to the fleetest does the race ever go, nor does the valiant victory always know, not to the cleverest does the money ever flow, nor does the wise stand always in grace's glow-because "chance and circumstance befall them all." Worse, he adds (9:12), no better than trapped fish and snared birds do people caught by misfortune grasp their situation when it suddenly befalls them.

In a fourth example, Qohelet sums up a proverb he has just examined in the context of a parable of his own making (9:I4-I6), about the advantage of the wise over weapons (9:18a), then follows it up with the irony that a single misstep can ruin a huge advantage (9:I8b). This leads him to compose his own proverbial, parabolic, parallelistic couplet (IO:I), that the intricate plan is foiled and the delicate article spoiled by the most common and random of things, the bug in the computer, the fly in the ointment, which he not only expresses semantically but also models syntactically: "Dead flies will rot, bubble 
the perfumer's ointment; more precious than wisdom, than honor is but a bit of folly." The form of the proverb illustrates its message: the nearly perfect parallelism is marred by doubled elements lacking the mere conjunction "and" in both its lines. The wry observation and its ironic formulation show Qohelet a master of the proverbial line and list and a disaster for proverbial wisdom; he can compose with the cleverest and undercut the concept of doing so, all at the same time.

Finally, Qohelet famously observes in a proverbial line that everything has its time, then illustrates with fourteen pairs of human phenomena, the repetitive form of which lulls the audience into a sense of order and balance, of rhythm and rhyme, of symmetry sublime (3:I-9). But Qohelet breaks the spell and bitingly goads: "So what is the point of doing any work at all?" (3:I0). This stinger posed as a rhetorical question suggests that in fact Qohelet quotes a wisdom-poem in order to reject it. The case, however, may be more interesting than that. The poem's list has long stymied efforts to account for all the items selected to appear in it; to explain all the pairings in it; to trace the order within each pair, from pair to pair, and from section to section; to make sense of the deviations from the poem's pattern; to determine the very syntax of the lines, which from the perspective of the beginning must comprise a series of separate sentences but from the perspective of the end must make up a single long sentence; and, above all, to render the key term for "time" ('et) uniformly. As it turns out, all the nagging departures from the poem's pull toward perfect patterning, the poem's stubborn resistance to its own symmetry, exemplify Qohelet's vexed observation that the most intricate plan is foiled and the most intricate article spoiled by the most common and random of things, the bug in the computer, dead flies in the ointment. That this observation so aptly describes the proverbial poem and that Qohelet composes the deliciously flawed proverbial line with ironic intent suggest together that Qohelet composes the poem as a 
parody. It mimics the wise, who absurdly persist in seeking patterns and willfully ignore patterns' inherent flaws and necessary failure. Where they see patterns, seasons, reliable repetitions whose identification can be turned to one's advantage, Qohelet sees a mirage, and beyond the mirage-incalculable, irreducible, unyielding luck and fate. Qohelet satirizes the human penchant for patternizing life though it has a way always of going awry. Symmetry, he argues, can never suppress serendipity.

Qohelet's radical break with constructive knowledge breaks as well with God-always the personified concept "God," never the distinct persona "Yahweh"-whom he presents as inscrutable, unpredictable, untraceable, unaccountable, and unknowable, indeed willfully and torturously so. He keeps humans distractedly busy, guessing anxiously, and ever exposed to the hazards of fate-all, Qohelet essays in a negative mode, so they fear him (I:I3; 2:24-26; 3:IO-I5; 5:I7-I9; 6:I-2; 7:I3-I4; 8:I7-9:I; I I:5). It is rather unclear, he says with bracing clarity, what happens to the human spirit, the life-essence, when a person dies and whether it and its conditions differ from those of an animal (3:I8-2I).

In framing the qohelet's philippic as a very long quote within a barelythere but dramatic teacher-student conversation, as a massive lesson unlearned and quickly retracted, the author of the work allows the audience to forget the frame or even to miss it, to feel directly addressed by the qohelet, and to yield to the force of the disquieting argument, and then at the end to distance itself from it. As a result, both the author and the audience can have their cake and eat it too-entertain a profound and profoundly disruptive thought as an experiment and also plausibly deny it. On the one hand, the trick is a linguistic one, uniquely facilitated by the textual medium. To read the text again is to experience the entire sequence all over again, the forgetting, the accepting, the denying. And yet, to have understood the thought once is never to be able truly to relinquish it, only to act as if having done so, 
knowledge or with certainty denying it, Qohelet says, life is a dialectic, like the experience of textual simulation itself.

\section{Narrative Omniscience}

The Hebrew Bible contains multiple works of prose narrative voiced by a third-person, external narrator of extensive knowledge and insight. ${ }^{19}$ Scholars have debated the origin and significance of this omniscient prose narrator, variously emphasizing its opposition to oral poetic polytheistic myth; ${ }^{20}$ its somewhat critical, secular cast; ${ }^{21}$ its distinctiveness from royally voiced literature, monumental and other, together with its national perspective; ${ }^{22}$ and its convergence with the divine perspective. ${ }^{23}$ More descriptively, the narrative form combines the advantages of the oral bard with those of the written chroniclea complete story (rather than aimless sequences of episodes) told in all the dry factuality of the prosaic voice (rather than the poetic, edifying voice of performance)-such that its narrators know the state of the universe when Yahweh began creating it; Yahweh's internal sentiments and reasoning; arcane knowledge and hoary lore, exotic as well as local; the origins of behavior, names, expressions, practices, and professions; ancient terminology, chronology, genealogy, and geography; and the sweep of extensive historical processes, including Yahweh's role and reasoning in them. Regardless of whether these narrative works counted as historiography or fiction at the time, the authors constructed the narrators as earnest and reliable. The narrators hold particular values and views, which inform their knowledge of what constitutes an event, its beginning point and conclusion, its causes and effects, and its significance. They might express ironic thoughts or view certain characters ironically, but they champion the form in which they speak and its salient feature, the construction of causality in time, which in their case frequently turns on Yahweh. 
Similar to the way the author of Qohelet challenges the typological knowledge claimed and produced by the poetic proverb-the way things are and how things happen-the author of Job challenges the knowledge of the singular claimed and produced by prose narrativethe way something was and how something happened. Similar, too, to the way the author of Qohelet has Qohelet mimic proverbial voices to demonstrate their fatuousness and has the framing scene present a failed chain of transmission, the author of Job presents an unreliable narrator, who tells a broken story with just enough threading between its parts to tempt the audience to insist on its coherence, and a main character who faces the challenge of refusing to tell a story, insisting on the brokenness of events, a sequence with no consequence. The author argues by way of poignant, multileveled illustration that human beings - the audience of the story no less than characters in it-will stop at nothing to make sense by narrativizing, by sequencing events to imply cause and effect. Markedly shifting styles, a detached, ironic, and discontinuous narrator, and a compromised, inconsistent Yahweh all keep the audience off balance, struggling to find interpretive and ethical purchase and to retell the story in a coherent and satisfying way.

Because the story of Job concerns the very phenomenon of storytelling, its interpretation turns precisely on how one retells it. Accordingly, my analysis consists of a guided retelling. The story concerns a pious man in the land of Utz (southeast of Israel and Judea) named Job, whom Yahweh tests by way of terrible calamity, who debates with his friends at length about the right response, and whom Yahweh restores. With these two names the author already signals the fictive nature of the work, that it puts the audience to the test, that it presents a thought-experiment about knowledge. The name Utz ('uș) reverberates with words for wisdom ('eșah) and counsel (y-'-ș), which appear throughout the book and are its theme, and the consonants in the name Job ('-y-w-b) make up both the exclamatory word of suffering $('-b-w-y)$, which represents Job's predicament, and also 
the noun "adversary" ('-w-y-b), namely, Job's position as a direct challenge to the wise and their traditional ideas of God, like the three friends, and as a direct challenge to God, whom Job calls upon to appear and justify him.

The story has three parts: (I) a stable backdrop against which a complication emerges; (2) the main character's response; and (3) closure, the sense that the character has handled the challenge, that the complication has been managed, and that a stable state of affairs has returned. They differ from each other so strikingly that scholars posit that two different works have been combined, one comprising parts I and 3 and another at part 2. The theory, though, does not account for the full set of phenomena: parts I and 3 have crucial points of discontinuity; the three parts do not shift neatly and sharply from one to another; features of one part show up at crucial points and in crucial ways in another; and important plot elements carry over from one to another to create interdependence. Rather, the author has crafted a story that hangs by several knotted threads, because storytelling itself is at issue.

In the first part (roughly chaps. I-2), the narrator tells about a remarkably conscientious and successful man, Job, whose ten privileged children could afford to feast together on a regular basis and did so in rotation, each one hosting all the others. At the end of each round, Job would hold a day of his own, offering Yahweh one animal for each child, in case any had had troublesome thoughts in the interim. One day, Yahweh's council of divine beings convenes. Yahweh speaks with one of them in particular about this remarkably conscientious Job, the sațan, who goads Yahweh to put Job to the test. An impossibly quick series of calamities decimates everything Job had cultivated and safeguarded for years, including all the people of his household-family members and subordinates alike. In a second round of attack, his own body is racked with pain, and he claws and writhes in agony. 
Though the narrative depicts a horrific scene, it carries the flat, detached, even ironic tone of a caricature, that unique combination of folk and mythic found in ancient materials. Job is perfect in behavior. The numbers around him are roundly perfect, based on seven and ten: seven sons and three daughters; 7,000 sheep and 3,000 camels; 500 teams of cattle and 500 donkeys. A divine council is described casually, neither through complex prophetic mediation nor prompted by significant drama in the human realm. Yahweh, allegedly in control, is manipulable and brings manipulation upon himself. He takes pride in a fine person, Job; admits to a logical argument that a test might be worthwhile; complains when Job passes that the test was done fruitlessly as if the suffering it entailed was not worthwhile; then admits to the logic that another round of testing is warranted. Yahweh creates trouble for his pride and glory, does not think matters through, changes his mind on what is worthwhile suffering, and comes across as less than majestic and august. This portrayal is disturbing for a work that seems to be about divine justice. The sațan-literally "antagonist" or "snare"-is a dynamic semi-villain who knows how to push Yahweh's buttons. The narrator who tells the story does so in a formalistic, highly repetitious, and disjointed way, as if unmoved by the horror unfolding and uninvested in the story he is telling, as when he relates the divine council reconvening (ז:6-г 2; 2:I-6), when he relates the various calamities befalling Job and his household (1:I3-I9), and when he casually repeats the blithe expression "one day" to sequence them (I:6, I3; 2:I). Wordplay, in which "the satan" (s-ț-n) describes his own activity as scouting the land (š- $w-t)$ and Yahweh accuses him of having incited him fruitlessly (s-w-t), produces such aesthetic pleasure as to distract from the horrific content of the story.

Repetition, a downright unusual cascade of personas echoing one another, works at multiple levels, at first sounding trite, at points poignant, and on reflection illustrating how speech can cross the divine/ 
ing of Job, "Now that man was consistent and straight, mindful and scrupulous" (I:I), and Yahweh uses these exact words to describe Job to the satan twice (г:8; 2:3). (2) In describing the onset of the calamities, the narrator says that Job's "sons and daughters were eating and drinking wine at the house of the eldest" (I:I3). The last of the series of survivors, the one who comes from that very feast, tells Job in the very same words, "your sons and daughters were eating and drinking wine at the house of the eldest" (I:I8). (3) After the calamities, Yahweh complains to the sațan that Job "persists in his fidelity" (2:3), and the sațan replies by sharpening his earlier claim (I:9-I I): direct discomfort and Job "will curse you to your face" (2:4-5). When the next level of suffering comes to Job, and he writhes in the dirt to try to dull his body's pain, Job's wife combines the words of Yahweh and the sațan and says to Job, "You persist in your fidelity; curse God and die" (2:9).

The sudden appearance of Job's wife, the realization that she did not die, and the sense-sheerly due to her omission-that she has come through (physically) unscathed all put the narrator in a positively dubious light. Through the description of all that Job had and lost, how could he have left out mentioning her, and now that he does, how so tangentially? Why not describe her circumstances, pain, questions, and accusations? The narrator quotes her remark to Job, "You persist in your fidelity; curse God and die!" but leaves it ambiguous whether she supports Job and wants to help him or blames him. Does Job suffer additionally because of her, either because she is suffering on his account or because she challenges him to give up? Not taking this wife and mother seriously as a character undercuts the narrator's pathos and earnestness, how real the calamity is to him. The disjunction between the narrator's style and the disturbing content produces a wry, even ironic effect. What kind of narrator is so casual and callous about a troubling story that ought to produce pathos? One who would seem to be winking at the narratee, an ironic one. 
In the transition toward the second part (2:I I-3:I)—still in prosethree friends come to console Job; they sit with him in silent horror. After a week, Job breaks the silence with a speech-in verse-that shocks the friends into action, and they begin several rounds of debate with him about his predicament (3:2-32:I). Each friend presupposes and makes the argument-proposes the story-that if all this happened to Job he must have deserved it, and that if he refuses to see that and fess up, he is responsible for perpetuating and deepening the situation. At the very least, he should admit a possible, forgotten offense, for to think a human can be so mindful and so perfect and allremembering all the time represents the absolute height of arrogance. It is unhuman; it is divine. But Job denies having slipped or having forgotten. He insists he has done nothing to deserve this. There are not causes; there is no such story here.

Whereas until this point in the story Job accepts what befalls him, as said twice by the narrator (I:22; $2: \mathrm{IOb})$ and once by Job in rather sharp reply to his wife (2:IOa), Job in this section considers himself trapped in a courtroom gone terribly wrong, where the persecutor, the accused, the witness, and the judge are all one, Yahweh. If Job's misery is taken by others to mean he deserves what has befallen him but he is certain he does not deserve it, then he is being slandered. So he calls upon Yahweh to appear and acknowledge his predicament by declaring that Job did not bring his misery upon himself. After a surprise fourth person, Elihu, appears out of nowhere and berates the three friends, not for being terrible consolers, but for failing to get Job to admit and repent (32:2-37:24), Yahweh himself appears and speaks to Job "from the whirlwind" (38:I-42:6). On the one hand, he berates Job for his audacity in summoning him. On the other, he does not say that Job deserves his suffering. One could make the case that this kind of appearance answers Job's call, exactly what he had in mind. 
There is no action at all in this part, just speech, a multiparty debate characterized by long speeches in verse, with all the techniques and devices of biblical verse on full display. As in a martial arts film, each friend takes a turn at Job and Job parries, in a kind of controlled melee. Job replies after each friend, then the next one goes: Eliphaz then Job, then Bildad then Job, then Zophar then Job. There's a complete second round, then a third, at the end of which the all-new character Elihu suddenly speaks up, after which Yahweh himself enters the conversation and speaks to Job "from the whirlwind." They too have several rounds. Yahweh describes creating the world and maintaining it, and challenges Job to match his sense of justice with what he knows about such things. Job relents. Yahweh presses the point and Job admits in terms that repeat Yahweh's own opening words.

There are several important points of continuity between these high-stakes rounds of theologizing and the opening set of scenes, between the second and first parts. The narrator carefully lays tracks for Job's transition from accepting to challenging. After the first round of attack, the narrator says, "Through all of this, Job did not sin or cast aspersions on God" (г:22), but after the second, "Through all this, Job did not sin with his lips" (2:I0); the contrast suggests a rising tide, a dam readying to break, which builds over a week of pregnant silence between Job and his friends, and finally bursts (3:I). Moreover, when the narrator introduces Job's speech he does so slyly, as if the aspersions are finally about to pass through his lips and he will curse God, but then he presents what feels like a twelfth-hour twist: "After that"-a week of miserable, possibly accusatory silence before his friends-"Job opened his mouth and cursed" not God but "his day" (3:I), namely, the day of his birth: would that he never had lived (3:322). Having begun the direct quoting of the debaters, the narrator comes forward minimally, only to introduce each of the speakers in turn. However, at the end of Job's final, extended speech to his friends, 
the narrator makes the unusually formal announcement, "here end the words of Job" (31:40), which sounds detached and has a deflating effect. Moreover, he then provides the inside view that the three friends gave up speaking at this point because they saw that Job was too convinced of being righteous (32:I), which fleetingly sides with them, as if forgetting the precipitating scenes.

The ironic stance evoked by the author in the portrayal of Job and Yahweh in the opening scenes also returns, at the very climax of the debates. When Yahweh finally appears and thunders at Job (38:I40:2), Job replies in abject humility, saying there is really nothing for him to say, and yet, he does so rather loquaciously, in a way that questions his sincerity: "Yes, I am made a lightweight. What could I reply? I have put my hand over my mouth. I have said a piece and shall not speak again, two and I shall not continue" (40:4-5). His hand is over his mouth but he keeps talking. He said a piece and does keep talking, two and there is more yet. And who announces that their hand is over their mouth? Were he doing that, Yahweh would see it. Only someone with a readership announces that. An earnest, realistic character is not supposed to know or acknowledge he or she is being read. Similarly, this admission by Job does not suffice for Yahweh, who then repeats himself at length in new terms (40:6-4I:26), until Job states yet again his lowliness (42:I-6) - this time by elegantly reusing Yahweh's thunderous opening words $(42: 3-4 ; 38: 2-3)$.

In fact, the entire verse debate occurs in unusually difficult Hebrew, with many forms and roots known especially from Aramaic. This has generated many questions and theories about the book: Was it originally written in another language, especially Aramaic? Did its author live in a time or in a region with a distinct Hebrew dialect? But it seems part of the literary effect; it is often a feature of poetry to use unusual speech, which can include elements that sound foreign, elements that sound archaic, and also elements that sound entirely new. ${ }^{24}$ In 
the case of this story, which sets all the characters in Utz, near or in Edom, the idea is the equivalent of having them speak with a foreign accent; they are meant to sound vaguely Edomite or "Eastern." The effect of all that foreign-sounding verse-speech keeps the audience attentive to and engaged in the literary quality of the work. Focusing the audience on the artistry at play in the extensive debate has the effect of distracting them, helping them to forget the specific terms of the precipitating scenes, which serves the discontinuity of the conclusion.

After Yahweh's conversation with Job, the story begins the transition to the third part. Yahweh turns to one of Job's three friends, chastising the three of them, vindicating Job to them, and insisting they set things aright with him (42:6-9). On the one hand, this segment concludes the debate scene; on the other, the narrator comes forward again, he employs a disjunctive formula normally reserved to introduce a new scene, "After Yahweh said these things to Job," and the segment occurs entirely in prose.

The story concludes with Yahweh bringing about Job's full restoration (42:IO-I7), in the terms of the losses from the story's opening and with its folktale feel. Job had lost seven sons and three daughters; these are all, as it were, replaced. His wealth is replaced-so fully replaced that his daughters were able to inherit full and equal portions alongside their brothers. Friends and relatives return to Job's orbit with consolation, camaraderie, and gifts. Job lives to the unusually ripe old age of 140 , and sees up to the blessed ideal of four generations. His fame and reputation secure, he dies feeling a complete man. The number schemes of the story's opening return too. Job gets double the animals: I4,000 sheep $+6,000$ camels; $\mathrm{I}, 000$ teams of cattle $+\mathrm{I}, 000$ donkeys. He has another seven sons + three daughters. He lives I 40 years, double the stereotypical or ideal 70 . Within that, the number seven is highlighted again: Job's friends should bring seven bulls and seven 
rams. The I4,000 sheep and Job's I40 years are multiples of seven. Job has seven sons, to which the narrator gives extra emphasis by the use not of the typical word for seven (shiv'ah), but an artificial, dialecticalsounding one (shivanah), though the narrator is not himself, as it were, from Utz (42:I3). In qualitative terms, the narrator provides the evaluative information that Job's three new daughters were the most beautiful anywhere (42:I5) and that Job died content (42:17).

Yahweh is drawn with more nuance, speaking less formulaically than in the opening scenes and less overwhelmingly than in the debate, but he also sounds angry in a familiar, human way, which continues the motif found in both of his compromised character. He repeats himself, saying to the friends twice, "You did not speak correctly of me like my subject Job did" (42:7-8). He refers to what he would like to do to Job's friends rather crassly as "outrageous things" (nevalah). He stutters a bit and gets tripped up when he instructs them to go to Job, using the expression "rather, except for, unless" (ki 'im) when it does not fit: "Go to Job and offer up a whole-burnt offering on your account, and Job my subject will petition for you. Rather / Except for / Unless his face will I countenance to avoid doing outrageous things to you" (42:8).

Other aspects of the conclusion bely the sense of restoration and the appearance of symmetry. The narrator provides the names of Job's three daughters, but not those of the sons, and like "Utz" and "Job" they are symbolic: Yemimah, Qetsiah, and Qeren-hapukh, which would evoke meanings like "Day-by-day," "Cut-off," and "Upsidedown-horn" (with foreigner's pronunciation of $p h$ as $p$ ), respectively. These bizarre and troubling names generate two contradictory responses. On the one hand, they are so strange as to be almost laughable. On the other hand, they suggest that Job has not actually healed. Underneath the façade of restoration festers a continuing trauma. In the same spirit, the moment chosen by the narrator to mention the 
return of Job's relatives and friends leaves it ambiguous as to whether they come after the material signs of his restoration, or beforehand and are the beginning of his restoration: how sincere are their presence and concern? It also raises the question as to where they were all this time. Why did the narrator not prepare for this moment? Creating such an ambiguity forces the audience to make do with what can be said: the relatives and friends came around and material possessions came back; the elements are all there, but the linkage is missing. Similarly, recalling the disjunctive repetition of "one day" in the opening scenes, the narrator does not indicate how much time has been passing, how long after the debate Yahweh begins restoring Job, and how long his restoration takes-one day, a week, a year, ten years. The effect of withholding a concrete sense of time makes the segment schematic and not fully real.

In fact, the narrator gaps even more boldly. As odd as it was that in the description of Job's collapsing fortunes he forgot, as it were, to mention Job's wife until she had something to say to him, the narrator omits her completely from Job's restoration. Did she die for her suggestion to Job? Did Job divorce her? Does she refuse to be consoled? By the same token, the satan and the council that set the scene and precipitated the complete turn of events do not return. Has the satan been banished, or is this a job well done? Does the sațan feel ashamed; does he claim everyone is a winner; or does he scheme against Job in some other way? The narrator provides the backstory-the divine council and the system test-but does not return to it.

Yahweh, too, seems a contradictory character. He chastises Job for audacious speech, which implies that Job's friends spoke well. After that, however, he chastises Eliphaz and the friends for what they said of Yahweh, and he vindicates Job for what he said. Similarly, much of the pathos in the debate between Job and his friends turned on the rarity and overwhelming character of Yahweh's appearance, which 
then occurs climactically with the sense of the near-miraculous. Afterward, though, Yahweh's speech to Eliphaz is presented with no fanfare at all, as an easy, regular, and unimpressive thing.

Finally, the story's coherence founders on the very idea of restoration. In addition to the wrinkle signaled by the names of Job's daughters and the trauma they encode, the ten children, their families, and all the masses of people in Job's household who died in the test cannot be restored. Job may have the numbers back, but not those individual people. More sharply, they did not deserve to die: the setup of the story, that all this suffering befalls Job as part of a "system check," now applies many times over to all those characters, each one of whom died not for their sins but because someone else, Job, was perfect! The story never admits this paradox.

All these forms of gapping and ambiguity, which undercut the sense of relief and return, leave the audience with nagging questions. The story has the form of restoration, a shadowy outline, but holes, too, the elements of a counter-story, and fractures that threaten the coherence and integrity of the story as a whole. It is tempting to infer that separate works have been combined, but out of the various parts of Job one cannot reconstruct even one complete and coherent story, let alone two or three. For instance, what could Job and his friends have said such that Yahweh approves Job's remarks and rejects those by the friends? Surely not the opposite of their current positions in the debate, with Job claiming he deserved calamity even if he cannot recall the egregious offense that warranted it, and the friends countering that Job should not self-centeredly make it about himself, since Yahweh is simply unpredictable and inscrutable. On the contrary, at the same time that the story has its deep problems, each part has been conceptualized and formulated to set each other up and refer back and forth.

This seemingly impossible situation of a story that both holds together and falls apart amounts to an exploration of the nature and 
the limits of storytelling itself. The author has taken the most significant, the most vital instance of cause and effect in human experience, fate and fortune in the biggest sense, ethics, divine reward and punishment, to explore the most extreme limits of how it can be put into story form.

It is standard for human beings to live by the story that misfortune is punishment deserved. At the time of offense we were mindless of what we were doing and now our frail human memory fails us, so we search back and repent of what was done or we just repent generally. This is the premise of the law of the cleansing sacrifice (hatțatt, regularly mistranslated "sin-offering") in Leviticus 4-5. And it was standard in ancient Israel and Judea to think that the members of a family are interdependent and that it was an act of divine patience and compassion to fraction out punishment over several generations to keep the family line alive. Misfortune could be explained as the result of an earlier cause, an ancestor's misdeed, handled by a patient and loving deity. This is a story: "My ancestor committed an offense and I suffer a fraction of it, and this is how Yahweh keeps alive my family line as a whole." The story of Job poses a conundrum that excludes the possibility of these stories of individual and family guilt: What if there were a man who was truly perfect, whose behavior rules out misdeeds and forgetting them? He knows for sure he has done no wrong and he keeps perfect account of his children. The devastation that befalls him is so total that it cannot be about him or his predecessors. What does that man do? What story does he tell? Can a story, any story, account for this?

The author works at two levels, doubling the challenge. There is the story Job will tell of himself and there is the story to tell about Job, how his situation arose and how it was resolved. Job refuses to tell a new story. He sticks to his own broken story. There is a situation now, his misery, and there is a situation before, his perfect faithful- 
ness; and they do not make a story. They are not cause and effect. He suffers, and there is no just explanation. The friends refuse to accept Job's nonstory. They push and push to corner him into telling the traditional story, the only just story they know: Job must have done something wrong. If Job is right, their ideas of life and how to live it are at risk. If the devastation centered on him has nothing to do with his behavior, what happens to their petty lives? This is a debate of the highest stakes. For Job, the only way out is for Yahweh to show up and at the very least affirm that Job does not suffer for a cause that lies with him, and this is just what Yahweh does. He berates Job's arrogance in calling on him, but he does not force a new story. He offers another nonstory, a non sequitur: Yahweh knows all, does all, and manages all, so that's that. Job can be humble because he can be pleased; his refusal to tell a story has been affirmed.

For the story about Job, the author chooses to put the necessary but unrealistic pieces into play, creating a story that hangs by the thinnest, most fragile of threads. There is a mythic backstory with Yahweh prompted by the satan, a wife whose only point of view is that of the man, and three unfriendly friends, three hostile consolers. There is what counts formally as a conclusion, but which really does not achieve proper closure. The author creates the sense of an ending, without actually providing one, the appearance of symmetry without its content. It is the theater of the absurd. Readers are pushed to the limits of what they can tolerate: a mythic background, a compromised God, justice threatened, a story, the ultimate human story, hanging by a thread always on the verge of snapping. And yet, the story just works, because by the end the audience somehow forgets the beginning, or pushes it out of mind just enough. The audience always reads with one eye closed, the beginning without the end and the end without the beginning, and insists somehow on making Job's story work.

In short, the book of Job is not a story about how God runs the world. It is a story illustrating how human beings survive in it. 


\section{Conclusion}

At least two culturally defined and definable spheres of experience served ancient Israelians and Judeans in their construction of knowledge, the royal and the domestic. ${ }^{25}$ The royal sphere, wrapped in the control of amounts of matter and numbers of people several magnitudes beyond the average, pointed to its visible, tangible accomplishments as evidence of divine will and expressed that certainty in writing. It can be construed as a spatial, horizontal knowledge. Two literary forms arose or crystallized in its orbit and attenuate its claims, the prophetic, which claimed unmediated, direct knowledge of divine will and voiced itself in competing first and second persons, and the anonymous, omniscient narrative voiced in the third person that recounts the foundational and even recent past. The domestic sphere, centered on household durability, took a family's very existence with identity intact as an indication that the accumulated wisdom of causes and effects-above all divine-has been successfully communicated and transmitted down generations. It can be construed as a temporal, vertical knowledge. The literary forms that arose from or crystallized this experience of household life transposed that certainty to the literary medium in instructional genres of varied voicing and scope, as reams of pithy sayings, series of riddles, and scenes of direct address voiced by different characters, whether named individuals or archetypes.

These written genres of certain knowledge-prophetic, narrative, and proverbial-drew reactions, counterarguments, by varied authors. In the face of a dramatic turn of events that seemed an opportunity but enjoyed no tangible proof, the author of Isaiah 40-48 reconceptualized the deity and history as so far beyond the senses and so utterly singular as to be identifiable and appreciable by sheer will alone. Bolstering the case, the author exploited the textual medium, which had long been employed to present itself as a record of a pro- 
phetic voice, such that the prophetic voice would speak directly, in real time, with every reading. Two more, of unknown historical prompting, presented clear-eyed views of the nature of human self-delusion and its genres of cause and effect. The author of Qohelet exploded the proverbial packing of quotidian knowledge for transmission across generations, in a prose lecture demonstrating its fatal flaws and, furthermore, situated that lecture within a failed act of transmission. The author of Job illustrated the unreliability of narrative as explanation, a form so dearly held by human beings as to be asserted and applied even in the most untenable of circumstances, when the divine sphere attacks the domestic for its very faithfulness. Both authors deny the knowability of divine will, the one by asserting divine aloofness, the other by presenting an irreverent parody. And both, in the course of exploiting the textual medium, rely on length to facilitate audience forgetfulness and drive home their point, that human beings schematize and assert coherence by selective attentiveness.

In addition to Isaiah 40-48 with its references to Cyrus and the capture of Babylon, Qohelet and Job bear signs-primarily linguistic - of the Persian period, in the sixth-fourth centuries BCE. It is tempting to attribute their authors' ruthless clarity to living in a period when imperial multinational control replaced native kingship, to a postmonarchic mood, and mark it as a stage in the development of IsraeliteJewish thought. But the author of Isaiah 40-48 seems to have turned back on his own insights several decades later in Judea, in Isaiah 49-66, and by the same criteria applied to Job and Qohelet, the book of Ruth, which seems so wistful about kingship, comes from the same period. The case is uncertain and can be overstated. The ancient readers of the materials eventually collected as a single Bible considered those materials to be as eclectic, exploitable, adaptable, and extendable as they were normative; they found in them not just divine knowledge, but the stuff out of which to fashion more. Rather than schematize and narrativize Jewish literary and religious develop- 
ments (often in the context of subsequent, Christian ones), contemporary readers of the Hebrew Bible would do best to recognize it and engage it as an ancient treasury of more ancient varied materialsearlier treasuries and compositions - of no exclusive or essential features, no single divine message or truth, no natural trajectory, but whose contents lend themselves to contemporary probing for salience, insight, and the inspiration and building blocks for new forms of knowledge. 


\section{Notes}

I. Menahem Haran, The Biblical Collection: Its Consolidation to the End of Second Temple Times and Changes of Form to the End of the Middle Ages, 4 vols. (Jerusalem: Bialik \& Magnes, I996-20I4 [Hebrew]), which depends upon on a prior series of articles by him: "Book-Scrolls in Israel in Pre-Exilic Times," Journal of Jewish Studies 33 (I982): I6I-73; "More Concerning Book-Scrolls in Pre-Exilic Times," Journal of Jewish Studies 35 (1984): 84-85; "Book-Scrolls at the Beginning of the Second Temple Period: The Transition from Papyrus to Skins," Hebrew Union College Annual 54 (1983): I I I-22; "Book-Size and the Thematic Cycles in the Pentateuch," in Die Hebräische bibel und ihre zweifache Nachgeschichte: Festschrift für R. Rendtorff zum 65. Geburstag, ed. E. Blum et al. (Neukirchen-Vluyn: Neukirchener, I990), I65-76; "Torah and Bible Scrolls in the First Centuries of the Christian Era," Shnaton Io (1986-89): 93-106 [Hebrew]; "Bible Scrolls in Eastern and Western Jewish Communities from Qumran to the High Middle Ages," Hebrew Union College Annual 56 (I985): 2I-62; "Codex, Pinax and Writing Slat," Scripta Classica Israelica I5 (I996): 2I 2-22; "Archives, Libraries and the Order of Biblical Books," Journal of Ancient Near Eastern Studies 22 (I993): 5I-6I.

2. See bibliography in Simeon Chavel, "The Face of God and the Etiquette of Eye-Contact: Visitation, Pilgrimage, and Prophetic Vision in Ancient Israelite and Early Jewish Imagination," Jewish Studies Quarterly I9 (2012): I-55, at 54 n. I68.

3. See, e.g., Konrad Schmid, The Old Testament: A Literary History (Minneapolis: Fortress, 20I2).

4. Barbara H. Smith, On the Margins of Discourse: The Relation of Literature to Language (Chicago: University of Chicago Press, I978); Benjamin Harshav, Explorations in Poetics (Stanford, CA: Stanford University Press, 2007); see also Milan Kundera, The Art of the Novel, rev. ed., trans. Linda Asher (New York: HarperCollins, 2000).

5. See Eva Mroczek, The Literary Imagination in Jewish Antiquity (Oxford: Oxford University Press, 2016). 
6. Mario Liverani, "The Deeds of Ancient Mesopotamian Kings," in Civilizations of the Ancient Near East, ed. Jack M. Sasson (I995; repr. 4 vols.; Peabody, MA: Hendrickson, 2000), 4:2353-66; Douglas J. Green, "I Undertook Great Works": The Ideology of Domestic Achievements in West Semitic Royal Inscriptions, FAT II, 4I (Tübingen: Mohr Siebeck, 2010).

7. The narrative at I Samuel I5:I2 shows at least one author to have imagined a founding king of Israel putting up a monument; that at 2 Samuel 8:I3 might show another. The poems at 2 Samuel 23:I-7; Psalms 2; 45; 72; 89; I Io present David, Solomon, and those of the dynasty as: speaking in Yahweh's voice, cast in Yahweh's awesome image, like his own son, divinely impregnable, of fierce divine beauty and justice, of eternal fame, braced by the divine arm, and divinely controlling vast territories and cosmic entities. See also the predictive texts at Isaiah I I:I-IO; 33:I3-24.

8. Marc Zvi Brettler, God Is King: Understanding an Israelite Metaphor, JSOT Supp. 76 (Sheffield: Sheffield Academic Press, I989); Mark S. Smith, "Like Deities, Like Temples (Like People)," in Temple and Worship in Biblical Israel, ed. John Day (London: Clark, 2005), 3-27.

9. Compare Robert P. Carroll, "Ancient Israelite Prophecy and Dissonance Theory," Numen 24 (I977): I35-5I, at I44-45; Robert P. Carroll, When Prophecy Failed: Cognitive Dissonance Theory in the Prophetic Traditions of the Old Testament (New York: Seabury, 1979), I30-46, esp. I32-38.

Io. Chavel, "Face of God," 32-30; Simeon Chavel, "Prophetic Imagination in the Light of Narratology and Disability Studies in Isaiah 40-48," Journal of Hebrew Scriptures I4/3 (2014): I-47, at 35-36.

I I. Chavel, "Prophetic Imagination."

I2. See Irving Finkel, ed., The Cyrus Cylinder (London: I. B. Tauris, 2013); Amélie Kuhrt, "Cyrus the Great of Persia: Images and Realities," in Representations of Political Power, ed. M. Heinz and M. H. Feldman (Winona Lake, IN: Eisenbrauns, 2007), I69-9I.

I3. Comparison of headings and sequence in the Hebrew and Greek Bibles yields nine sections: (I) I:I-9:I8; (2) IO:I-22:I6; (3) 22:I7-24:22; (4) 24:23-34; (5) 25:I29:27; (6) 30:I-I4; (7) 30:I5-33; (8) 3I:I-9; (9) 3I:IO-3I, with Solomon standing at the head of sections 1,2 , and 5 . The discussion here draws upon the breakthrough work by Jacqueline Vayntrub, "Proverbs and the Limits of Poetry" (PhD diss., University of Chicago, 20I5), on Proverbs, biblical poetry, and the Hebrew term $m$-š-l. 


\section{KNOW: A JOURNAL ON THE FORMATION OF KNOWLEDGE}

I4. Simeon Chavel, "Literary Theory and Biblical Literature: Levels of Speakers in Qohelet and Song of Songs," paper prepared for Society of Biblical Literature National Meeting, Baltimore, November 23-26, 2013, and "The Utility and Futility of Poetry in Qohelet," in Close Readings: Biblical Poetry and the Task of Interpretation, ed. Elaine James and J. Blake Couey (Cambridge: Cambridge University Press, forthcoming).

I5. All translations of the Hebrew Bible into English are mine.

I6. See a good treatment of the problem in Jennie Barbour, The Story of Israel in Qohelet: Ecclesiastes in Cultural Memory, Oxford Theological Monographs (Oxford: Oxford University Press, 2012), I0-36.

I7. Compare Prov. 4:4; 7:2; 19:16; and the entire passage at 7:I-27.

I8. Compare Prov. I5:27: "Who does greedily afflicts his home; who spurns gifts lives."

I9. On the important distinction between authors, implied authors, and narrators, see Shlomith Rimmon-Kenan, Narrative Fiction: Contemporary Poetics (New York: Methuen, I983; repr., London: Routledge, I989); Mieke Bal, Narratology: Introduction to the Theory of Narrative, 3rd ed. (Toronto: University of Toronto Press, 2009).

20. Umberto Cassuto, Biblical and Oriental Studies, 2 vols., trans. I. Abrahams (Jerusalem: Magnes, I973-75), "The Israelite Epic," 2.69-I09 [Hebrew, I943], and "The Beginning of Historiography among the Israelites," I.7-I6 [Hebrew, I95 I]; Robert S. Kawashima, Biblical Narrative and the Death of the Rhapsode (Bloomington: Indiana University Press, 2004); David Damrosch, The Narrative Covenant: Transformations of Genre in the Growth of Biblical Literature (Ithaca, NY: Cornell University Press, I987 [I99I]).

2I. Gerhard von Rad, "The Beginnings of Historical Writing in Ancient Israel," in The Problem of the Hexateuch and Other Essays, trans. E. W. Trueman Dicken (Edinburgh: Oliver \& Boyd, I966), 166-204 [German, 1944].

22. John Van Seters, In Search of History: Historiography in the Ancient World and the Origins of Biblical History (New Haven, CT: Yale University Press, I983); Seth L. Sanders, The Invention of Hebrew (Urbana: University of Illinois Press, 2009).

23. Meir Sternberg, The Poetics of Biblical Narrative: The Poetics of Biblical Narrative; Ideological Literature and the Drama of Reading (Bloomington: Indiana University Press, I987).

24. T. V. F. Brogan, "Archaism," in The New Princeton Encyclopedia of Poetry and Poetics, ed. Alex Preminger and T. V. F. Brogan (Princeton, NJ: Princeton University 
SPRING 20 I 8

25. "Israelians" = people who live in the kingdom of Israel (in the north). "Judeans" = people who live in the kingdom and former kingdom of Judea (in the south). "Israelites" = an entity projected by the Bible that comprises both Israelians and Judeans. 